\title{
INDÍGENA NA CIDADE? \\ CONSIDERAÇÕES SOBRE A EDUCAÇÃO INTERCULTURAL NA ESCOLA
}

\author{
Aila Oliveira Serpa $a^{i}$ \\ Beleni Saléte Grando ${ }^{i i}$
}

\begin{abstract}
Resumo: O direito do indígena de viver e ser reconhecido em sua especificidade onde quer que viva, na aldeia ou na cidade, tem relação com o reconhecimento do "outro" nestes contextos. Consideramos que para entender essas relações em espaço urbano e mais especificamente, em escolas urbanas, é necessário compreendermos esses espaços como fronteiras interétnicas nas suas dimensões socioculturais, que ambientam e embasam as relações que neles ocorrem como possibilidades de novas e outras identidades que se definem nesses espaços de fronteiras interculturais. Neste trabalho, trazemos estudos que nos auxiliam na compreensão dos contextos interétnicos, como as escolas urbanas em Mato Grosso, em que alunos indígenas ocupam esse espaço e a demanda por uma educação intercultural se impõe como imperativo. No intuito de compreender como a escola e seus professores engendram a formação continuada e trazem novos conhecimentos e práticas para o cotidiano da escola, fizemos a análise do Projeto Sala de Educador (PSE), dos anos de 2011 a 2015, de uma escola Estadual no município de Nova Xavantina - MT. Os dados nos revelam um persistente fracasso escolar dos alunos indígenas. A escola que deveria representar a possibilidade de aprender a se relacionar com a sociedade envolvente sem perder ou desqualificar sua própria cultura, infelizmente não cumpre seu papel. Sendo assim é imprescindível que todos os educadores se apropriem de conhecimentos básicos sobre os povos indígenas do Brasil: quem são, quantos são, como vivem, aspectos próprios de cada cultura, como se organizam, entender a trajetória histórica e cultural desses povos e daqueles que circundam as escolas e cidades, suas estratégias e resistência para manutenção de sua cultura e de seus direitos enquanto povos diferenciados e, ainda assim, pertencentes à sociedade nacional.
\end{abstract}

Palavras-chave: escolarização indígena; urbanidade indígena; interculturalidade.

\section{INDIGENOUS IN THE CITY? CONSIDERATIONS ON INTERCULTURAL EDUCATION IN SCHOOL}

\begin{abstract}
The right of indigenous people to live and be recognized in their specificity wherever they inhabit, be it in their village or in the city, is related to the recognition of the "other" in these contexts. We consider that in order to understand these relationships in urban space and more specifically in urban schools, it is necessary to understand these spaces as interethnic boundaries in their socio-cultural dimensions, which embody and support the relations that occur in them as possibilities of new and other identities that are defined in these spaces of intercultural boundaries. In this work, we bring studies that help us to understand the interethnic contexts, such as the ones at urban schools in Mato Grosso, where indigenous
\end{abstract}

Revista Interinstitucional Artes de Educar. Rio de Janeiro, V. 4 N. 3 - pag 623-654 (out/2018 - jan/ 2019) 
students occupy this space and the demand for an intercultural education is imperative. In order to understand how the school and its teachers engender their continuing education and bring new knowledge and practices to the school's everyday routine, we analyzed the Educator Room Project (PSE), from 2011 to 2015, of a State school in the township of Nova Xavantina - MT. The data reveal a persistent school failure among indigenous students. The school, which should represent the possibility of learning to relate to the surrounding society without losing or disqualifying its own culture, unfortunately, does not fulfill its role. Therefore, it is imperative that all educators acquire basic knowledge about the indigenous people of Brazil: who they are, how many there are, how they live, aspects specific to each culture, how they organize themselves, to understand the historical and cultural trajectory of these people and those that surround schools and cities, their strategies and resistance, as well as the maintenance of their culture and their rights as distinct people, while also belonging to the national society.

Keywords: indigenous schooling; indigenous urbanity; interculturality.

\section{Introdução}

O direito do indígena de viver e ser reconhecido em sua especificidade onde quer que viva, na aldeia ou na cidade, tem relação com o reconhecimento do "outro" nestes contextos. Consideramos que para entender essas relações em espaço urbano e mais especificamente, em escolas urbanas, é necessário compreendermos esses espaços como fronteiras interétnicas nas suas dimensões socioculturais, que ambientam e embasam as relações que neles ocorrem como possibilidades de novas e outras identidades que neles se definem nesses espaços de fronteiras interculturais.

A escola e o modo como cada grupo étnico se relaciona com esta instituição varia muito e de acordo com dinâmicas particulares. Os estudos sobre a Educação Escolar Indígena (EEI), já bem desenvolvidos, propõem que se a identidade étnica não é uma essência e sim um produto relacional, no lugar de uma visão dualista da escola - ameaça ou conquista propõe-se a escola como um espaço de contato (TASSINARI, 2001), ou nos termos de Grando (2004) e Barth (1998) uma fronteira. Acrescentamos aqui que essa concepção também é valida para as escolas urbanas que recebem indígenas.

No espaço urbano e em todas as escolas não indígenas, o movimento dos Povos Indígenas do Brasil conquistou o direito de ter inserido nos currículos suas histórias e culturas a fim de que a sociedade possa reconhecer a diversidade e respeitá-la em suas especificidades,

Revista Interinstitucional Artes de Educar. Rio de Janeiro, V. 4 N. 3 - pag 623-654 (out/2018 - jan/ 2019) 
por meio da Lei 11.645/08 iii (BRASIL, 2008), pois se trata de um amparo legal que busca mais uma possibilidade de reconhecimento da diversidade cultural brasileira, além de uma nova abertura de espaços de fronteiras e de (re)afirmações de identidades múltiplas em todo o país.

Essa lei possibilita o reconhecimento da escola tratar dos conflitos interétnicos que estão presentes nas formas como o imaginário social coloca os povos indígenas e não reconhece suas inúmeras contribuições para a constituição sociocultural e econômica da formação do Brasil como o conhecemos hoje. Esse imaginário social tem reproduzido na escola a existência de relação expressa por conflitos latentes e não declarados que irá, provavelmente, marcar a presença dos estudantes indígenas nas escolas da cidade. Esses contextos são caracterizados por Neves (2012) como "a reedição do contato", ou seja, as relações nas escolas urbanas apontam relações de estranhamento entre os estudantes indígenas e os não indígenas - estudantes, docentes e gestores (as) - que explicitam alto grau de desconhecimento sobre os Povos Indígenas, como verificado em vários estudos sobre essa relação (REZENDE, 2004; OLIVEIRA, 2013; ROSA, 2008; SOUZA, 1997; BOTH, 2006; EICHHOLZ, 2015).

Como uma superação das ideias de aculturação e assimilação, a etnicidade mostra as resistências e permanências do diferente em meio ao nacional, já que ela se manifesta, necessariamente, na intensificação das interações entre diferentes grupos. A etnicidade necessariamente aparece na fronteira, ou seja, no compartilhamento de um contexto social que revela, acentua e marca as diferenças culturais. A fronteira é, segundo Martins (1997), o lugar primordial da alteridade:

[...] que faz dela uma realidade singular. À primeira vista é o lugar do encontro dos que por diferentes razões são diferentes entre si, como os indígenas de um lado e os civilizados de outro; como os grandes proprietários de terra, de um lado, e os camponeses pobres de outro. Mas o conflito faz com que a fronteira seja essencialmente, a um só tempo, um lugar de descoberta do outro e de desencontro. Não só o desencontro e o conflito decorrentes das diferentes concepções de ida e visões de mundo de cada um desses grupos humanos. O desencontro na fronteira é o desencontro de temporalidades históricas (MARTINS, 1997, p. 151).

Revista Interinstitucional Artes de Educar. Rio de Janeiro, V. 4 N. 3 - pag 623-654 (out/2018 - jan/ 2019) 
Para que de lugar primordial a fronteira se torne lugar de fato lugar da alteridade, compreendemos, com Marín (2010) que as sociedades devem aprender a (com)viver num ambiente intercultural.

A interculturalidade pode ser e entendida como:

[...] uma prática de vida que pressupõe a possibilidade de convivência e coexistência entre culturas e identidades. Sua base é o diálogo entre diferentes, que se faz presente por meio de diversas linguagens e expressões culturais, visando à superação da intolerância e da violência entre indivíduos e grupos sociais culturalmente distintos (LUCIANO, 2006, p. 50-51).

A partir de Bhabha, Fleuri (2003) considera que intercultura refere-se a um complexo e múltiplo campo em que sujeitos, perspectivas, epistemologias, práticas e políticas se encontram em "entrelugares" que possibilitam repensar e se abrir ao outro e ao outro dentro de si, com reconhecimento da alteridade e como possibilidade e efetivação até mesmo dos direitos humanos.

Ou, ainda como diz Martins (1997) a alteridade como direito se dá:

Quando os tempos se fundem, quando a alteridade original e mortal dá lugar à alteridade política, quando o outro se torna a parte antagônica de nós. Quando a História passa a ser nossa História, a História da diversidade e pluralidade, e nós já não somos nós mesmos porque somos antropofagicamente nós e o outro que devoramos e nos devorou (MARTINS, 1997, p.151).

Considerando o imaginário social brasileiro, pautado no etnocentrismo e no preconceito consolidado em relação aos indígenas, as relações de alteridade demandam uma aprendizagem, isso significa que para realização da alteridade e de relações interculturais nas "fronteiras", ou nos "entrelugares", principalmente se essa "fronteira" é uma cidade ou mais especificamente uma escola urbana, é necessário, além de outras coisas, um sistema de ensino baseado em uma educação intercultural.

Segundo Grando (2004), por educação intercultural entende-se uma prática educativa que reconhece nas diferenças de cada pessoa o direito universal de ser único como humano, e 
por isso mesmo, garante a todas as pessoas o direito ao acesso aos bens culturais e científicos produzidos pela humanidade, onde o lócus privilegiado desse direito é a escola, principalmente a escola urbana.

Para Luciano (2006) um novo sistema educacional pautado nos pressupostos da interculturalidade e da plurietnicidade se faz urgente para superar os atuais pontos de estrangulamento do processo de educação escolar indígena, em que não são somente as lideranças indígenas que precisam aprender a trabalhar e conviver com o mundo dos brancos, este também deve aprender a trabalhar e convier com os Povos Indígenas: Só assim a ideia da interculturalidade será praticada e vivida, o que é essencial para que o Brasil seja verdadeiramente democrático e pluriétnico (2006, p. 70).

Os processos educacionais engendrados em escolas com a presença de populações indígenas, ribeirinhas, quilombolas, etc. passam a ser destaque, pois é a partir deles que poderemos promover uma educação intercultural e significativa para todos, que os reconheça como sujeitos de história e conhecimento.

Apesar das diretrizes e referências nacionais, cada Estado gere a educação com base em linhas políticas diferentes, como afirma Mubarac Sobrinho: O traço geral das políticas que existem é que elas têm foco em grupos que vivem aldeados nas cidades. Ou seja, uma criança indígena que frequenta uma escola de maioria não indígena raramente vê tratados temas ligados à sua realidade étnica em sua escola (2010, p.53).

Para este autor a escola deveria representar a possibilidade de aprender a se relacionar com a sociedade envolvente sem perder ou desqualificar sua própria cultura; o que não é verificado nas escolas urbanas por ele estudadas em que há a [...] desvalorização da cultura Sateré-Mawé e a supervalorização da cultura urbana que visa massificar os grupos minoritários e invisibilizá-los (2014, p. 151).

Consideramos ser importante que novos estudos busquem compreender o indígena na cidade, fugindo das dicotomias limitantes nessa compreensão e promovendo o diálogo entre os mundos e suas culturas em contato na escola, espaço privilegiado de socialização; o que pode ser uma saída para repensar o papel e as práticas da escola para constituição da alteridade e efetivação da lei 11.645/08.

O texto apresentado é um recorte da pesquisa desenvolvida em nível de mestrado cujo lócus foi uma Escola Estadual de Ensino Médio do município de Nova Xavantina, Mato 


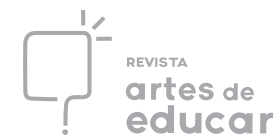

Grosso. O município se localiza em antigo território do Povo Xavante que atualmente não mais tem nele espaço demarcado, mas o busca para inserção dos jovens à escolarização, mesmo que esses são invisibilizados pelos educadores e munícipes. A pesquisa teve como foco compreender esse espaço a partir da análise documental e dos relatos dos professores a partir das temáticas da formação continuada na escola estadual tendo por referência a presença desses indígenas e seus impactos nos resultados finais. Os resultados denunciam a imperativa necessidade de se implementar uma formação mais sistemática no que tange a educação intercultural e aos conhecimentos para consecução da Lei 11.645/08.

Neste trabalho, trazemos os estudos que nos auxiliam a compreensão dos contextos interétnicos nas escolas urbanas em Mato Grosso, quando os alunos indígenas ocupam esse espaço e como a demanda da educação intercultural se impõem como imperativo o reconhecimento das dificuldades dos professores atender ao que explicita a Lei 11.645/08.

\section{Breve contexto da fronteira interétnica: lócus da pesquisa}

Nova Xavantina é um município do interior de Mato Grosso, constituído por diferentes grupos sociais e culturais; Oliveira (2010) considera que este município é palco de encontro de diferentes grupos étnico-culturais, principalmente os Xavante (seu habitante mais antigo), os Pioneiros (que aqui se estabeleceram por conta da Marcha para o Oeste) e por fim os Gaúchos (emigrados do sul na década de 1970, devido a conflitos agrários naquela região). Foram duas as formas principais de ocupação oficial: a primeira, no período de meados da década de 1930 até a década de 1960, pelos projetos de expansão da fronteira agrícola em meio a Marcha para o Oeste e, o segundo, a partir da década de 1970 por meio de projetos de colonização oficial e privados. Ambas as frentes de ocupação do território em que hoje se encontra Nova Xavantina desconsideram a presença de Povos Indígenas como fator a ser pensado nesse processo ( $c f$ OLIVEIRA, 2010; FRANÇA, 2000; CARPETNIERI, 2008; Teixeira, 2006).

[...] é indispensável lembrar que esse espaço já era ocupado pelos indígenas da etnia Xavante pelo menos desde 1820. Logo, a diversidade no espaço citadino é latente, sendo o cotidiano marcado pela diferença. Essa diversidade revela a cidade como campo empírico privilegiado para estudos sobre a interação entre esses grupos (OLIVEIRA, 2010, p. 10). 
Com base em dados do Projeto Político Pedagógico (2015) podemos dizer que a partir de 2011 a escola passou a atender exclusivamente o Ensino Médio e a incluir a modalidade de Ensino Médio Integrado ao Ensino Profissionalizante (EMIEP) com o curso Técnico em Informática. Durante a pesquisa, esta escola atendeu nos três turnos alunos com variadas características socioeconômicas, culturais e religiosas, alunos de todos os bairros da cidade e Xavante.

Considerando o contexto histórico, social, cultural de Nova Xavantina e da juventude em meio ao Ensino Médio, a escola em si se mostra como espaço de fronteira na qual o jovem de diferentes escolas de ensino fundamental, de todos os bairros da cidade, de diferentes origens e histórias se encontra, se descobrem e marcam suas identidades em movimento.

Seu espaço físico é referência no município e região e, com base em sua observação trata-se estrutura com boa manutenção, composta por 11 salas de aulas, sala de recursos, direção e outra de coordenação pedagógica, todas climatizadas; uma sala de professores e uma sala de hora-atividade inaugurada em 2014, também climatizadas; uma secretaria, uma Biblioteca, além de um Centro Esportivo (constituído de 02 quadras poliesportivas cobertas, arquibancadas, bebedouro, vestiários, um ambiente que serve para cantina, utilizado em eventos proporcionados pela escola) e dos dois laboratórios de informática e um laboratório de ciências parcialmente equipado. Por fim conta ainda com um Centro de Lazer e Cultura, composto por auditório e cozinha (climatizados), cantina, e refeitório com bebedouros.

Estes espaços servem à comunidade escolar em diversas ocasiões. No dia a dia são compartilhados e utilizados em aulas. Os dois laboratórios de informáticas são divididos para diferentes usos: um é de uso prioritário das turmas e alunos do curso técnico em informática, pois abriga recursos e utensílios para aulas teóricas e práticas do mesmo; o outro é de uso comum para professores, alunos e funcionários que desenvolvem aulas, projetos ou trabalhos. Há como pré-requisito de utilização dos mesmos o agendamento com um dos técnicos responsáveis e a entrega de uma ficha em que constam dados como professor responsável, a turma, os objetivos, conteúdo e metodologia da aula, quando este é o caso, ou a requisição do técnico para auxílio na atividade a ser desenvolvida no laboratório.

O laboratório de ciências também possui uma ficha de agendamento, entretanto tanto professores quanto alunos entendem que este laboratório é pouco utilizado, sendo que ocorre 


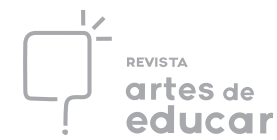

até mesmo a perda de materiais e elementos do mesmo, pois vencem o prazo de validade ou estragam por falta de utilização, mesmo que em 2015 tenha sido proposto um projeto para revitalização do laboratório de ciências, que só veio a ser realizado no ano de 2016.

Sendo assim, esses laboratórios se mostram como espaços de convivência para além das aulas disciplinares e fechadas em turmas, configurando-se como espaços de contato e de fronteira entre diferentes grupos e indivíduos, que frequentam, circulam e utilizam a escola.

Os espaços coletivos se mostram como espaços privilegiados e de convívio entre os diferentes grupos dentro da escola, posto que sejam abertos aos membros da escola e da comunidade. Entre esses espaços, destacamos a biblioteca que é aberta a comunidade e serve de ponto de encontro e estudos de alunos e professores, como a própria formação continuada em serviço realizada por meio do Projeto Sala de Educador que analisamos na pesquisa. Outro espaço relevante é o centro de cultura e lazer, além de ser o espaço mais utilizado nas horas dos intervalos, possui auditório onde são realizadas as horas cívicas, palestras, apresentações de teatro e outras atividades culturais e científicas dentro da escola.

Entendemos que por serem espaços de fluxos, de encontros, de contatos dos sujeitos da escola para além das regras e condicionamentos da "aula", eles se mostram extremamente significativos e polissêmicos. É onde os imponderáveis da escola se manifestam, onde os conflitos declarados e velados se perpassam, onde o "eu" e o "outro" se encontram e por isso mesmo se identificam e diferenciam, onde as diferenças se sobressaem, afinal, não se está na aula, onde "todo mundo é igual", por fim, onde as fronteiras etnicoculturais se realizam. Esses espaços são assim, relevantes espaços para a promoção da Educação Intercultural, mas para tal, os professores devem ter acesso à formação contínua que dê suporte à elaboração de projetos interdisciplinares e interculturais e que possam nesses valorizar a história e cultura do Povo Xavante, originário do atual território urbano delimitado pela cidade.

\section{Compreendendo a Educação Intercultural na escola urbana}

O Brasil possui uma população indígena minoritária que representa, entretanto, uma enorme diversidade, atualmente atualizada em aproximadamente 900 mil indivíduos, distribuídos em 240 povos: “[...] o que representa mais da metade do total de etnias encontradas em toda a América Latina" (RUSSO, 2005, p. 36). Cada um desses grupos

Revista Interinstitucional Artes de Educar. Rio de Janeiro, V. 4 N. 3 - pag 623-654 (out/2018 - jan/ 2019) 
étnicos têm uma história de contato e uma relação com a sociedade nacional e, algumas vezes, até um mesmo grupo étnico possui diferentes histórias de contato segundo cada subgrupo ou clã, como no caso dos Xavante.

Luciano (2006) considera que os Povos Indígenas do Brasil são grupos étnicos que ao longo de sua história de mais de 500 anos de colonização foram obrigados a reprimir e negar suas identidades e culturas, por força de repressão física e cultural, motivada principalmente por interesses econômicos; o que promove uma dinâmica e relação com a identidade própria à cada povo e cada história e situação de contato e relação com a sociedade envolvente.

$\mathrm{O}$ índio genérico, quer seja considerado o bom selvagem, quer o feroz silvícola, conforme Luciano (2006) não existe de fato, mas existe fortemente ancorado no imaginário popular e é fruto da ignorância e preconceito com relação à diversidade cultural dos povos nativos da América. Em sua análise sobre a percepção que o não indígena tem do indígena, o autor considera que a chegada dos Portugueses e outros europeus que se instalaram em terras brasileiras nos idos de 1500 foi um momento crucial de formação das percepções e imagens sobre o indígena brasileiro.

[...]os habitantes nativos foram alvo de diferentes percepções e julgamentos quanto às características, aos comportamentos, às capacidades e à natureza biológica e espiritual que lhes são próprias. Alguns religiosos europeus, por exemplo, duvidavam que os índios tivessem alma. Outros não acreditavam que os nativos pertencessem à natureza humana, pois, segundo eles, os indígenas mais pareciam animais selvagens. Estas são algumas maneiras diferentes de como "os brancos" concebem a totalidade dos povos indígenas a partir da visão etnocêntrica predominante no mundo ocidental europeu. Dessa visão limitada e discriminatória, [...] resultou uma série de ambiguidades e contradições ainda hoje presentes no imaginário da sociedade brasileira e dos próprios povos indígenas (LUCIANO, 2006, p. $34)$.

Para abordar essa questão Nunes (2010) traz sua concepção de indigenismo no Brasil, entendido a partir de Ramos (1998), a qual vai para além do conjunto de ideias referentes à incorporação desses povos ao Estado Nacional e inclui todo o vasto imaginário que se tem a respeito destes povos, desde o que é vinculado nas mídias, passando pelas noções dos grupos

Revista Interinstitucional Artes de Educar. Rio de Janeiro, V. 4 N. 3 - pag 623-654 (out/2018 - jan/ 2019) 
militantes e até mesmo as concepções da antropologia, construindo um arcabouço de noções sobre alteridade, identidade, etnicidade e nacionalidade.

Os relatos históricos, acadêmicos e populares sobre os Povos Indígenas do Brasil, poderiam afirmar que sofrem de um caso crônico de etnocentrismo, em que as perspectivas e adjetivações desses povos se basearam em noções/lentes europeias e os contaminaram até hoje de: observações e relatos histórico conforme o ponto de vista e interesse do colonizador capitalista, sempre carregado de estereótipos e preconceitos, reproduzidos até mesmo pelo sistema escolar (REZENDE, 2004, p. 29).

Luciano (2006) sintetiza essas perspectivas a respeito das imagens que predominam sobre o indígena do Brasil em três:

a) Visão romântica, presente desde a chegada dos primeiros europeus ao Brasil e que perdura até hoje nas figuras jurídicas da FUNAI e da tutela. O indígena é concebido como um ser "[...] ligado à natureza, protetor das florestas, ingênuo, pouco capaz ou incapaz de compreender o mundo branco com suas regras e valores" (LUCIANO, 2006, p.35);

b) A segunda perspectiva, também presente desde a invasão portuguesa tem fundamento econômico e perdura até hoje, na visão daqueles que tomam o indígena como selvagem, cruel, bárbaro, canibal, preguiçoso, traiçoeiro e outras denominações e adjetivos negativos, com objetivo de desqualifica-lo e justificar a extinção desses povos em função de posse de terras e desenvolvimento econômico (LUCIANO, 2006).

c) A terceira perspectiva surgiu mais recentemente com a promulgação da Constituição Federal de 1988 e se baseia numa concepção dos indígenas como sujeitos de direitos e de uma cidadania diferenciada e plural (LUCIANO, 2006).

Ainda assim, este autor é bastante otimista sobre as mudanças na perspectiva do não indígena sobre o indígena:

A opinião pública [...] confirma uma tendência percebida na prática cotidiana dos povos indígenas: a do aumento progressivo de pessoas e de segmentos sociais que vão superando a visão estereotipada sobre os primeiros habitantes do Brasil. Dito de outra forma, há uma consciência cada vez maior de que os povos indígenas constituem, sim, um dos pilares da sociedade brasileira e é uma referência importante, senão central, a 
identidade nacional, assim como é o negro, sem os quais o Brasil não é possível ser ele mesmo. Este caminho para o reencontro com sua história e sua origem pode significar um reencontro consigo mesmo, única possibilidade de seu desenvolvimento pleno, justo, democrático e igualitário diante da diversidade étnica e cultural de seu povo (LUCIANO, 2006, p. 38).

A partir destas perspectivas e da patente dinâmica de representações sobre os Povos Indígenas caminhamos para o seguinte questionamento: mas qual, afinal, é a identidade indígena?

A denominação índio ou indígena, de maneira geral, significa nativo, natural de um lugar, além de ser o nome genericamente dado aos primeiros habitantes do continente americano, que, como apresentado anteriormente representam uma enorme diversidade étnica. Esta denominação por muito tempo gerou uma identidade negativa, pejorativa, fazendo com que muitos povos escondessem sua indianidade (LUCIANO, 2006). Com o surgimento do movimento indígena organizado a partir da década de 1970, os Povos Indígenas do Brasil chegaram à conclusão de que era importante manter, aceitar e promover a denominação genérica de índio ou indígena, como uma identidade que une, articula, visibiliza e fortalece todos os povos originários do atual território brasileiro e, principalmente, para demarcar a fronteira étnica e identitária entre eles, os habitantes nativos, e aqueles que vieram de outros lugares e chegaram depois (LUCIANO, 2006; RAMOS, 1980).

O processo de reafirmação das identidades étnicas, articulado no plano estratégico pan-indígena por meio da aceitação da denominação genérica de índios ou indígenas, resultou na recuperação da auto-estima dos povos indígenas perdida ao longo dos séculos de dominação e escravidão colonial. O índio de hoje é um índio que se orgulha de ser nativo, de ser originário, de ser portador de civilização própria e de pertencer a uma ancestralidade particular (LUCIANO, 2006, p. 33).

Etimologicamente a identidade é derivada do termo latim, identitat e significa "o mesmo", demarcando a existência "do mesmo" e, necessariamente, "do outro"; o pertencimento ao mesmo ou ao outro, assim como sua exclusão, foi por muito tempo marcado pelo conceito de cultura (JOHNSON, 1997). 
Quando pensamos em identidade há que se superar a ideia de essência imutável e inata ao homem, concebemos identidade aqui como um processo, portanto contínuo, inacabado, relacional e dinâmico; trata-se de um fenômeno social que passa por um processo de atribuição, sustentação, transformação, no e pelo meio social, em que se destacam as "fronteiras" que separam e colocam em contato essas identidades (HALL, 2001). Esse espaço social de (des)encontros/contatos é o espaço de cada sociedade ou grupo social, ou seja, são os espaços e tempos determinados pela cultura.

Segundo Grando (2004), a partir de Geertz, a cultura é tecida nas relações sociais, nas interações entre indivíduos/grupos, indo para além de padrões comportamentais apreendidos e repetidos em equilíbrio, trata-se de atualizações e reiterações que ocorrem em conflito, dada natureza conflitiva das relações sociais. Ainda de acordo com o Johnson (1997) é preciso diferenciar no processo de interação social aquilo que é comportamento (tudo que o indivíduo faz) e aquilo que é ação (comportamento intencional baseado na pressuposição de como os outros irão reagir), sendo que na interação, a relação social se dá em grande medida pela ação.

Geertz (2001) considera a cultura como uma teia de significados que amarra o homem ao social; uma teia produzida em meio a um sistema de significados historicamente e socialmente construídos e expressos de forma simbólica, na qual os homens compartilham e desenvolvem suas atividades em relação à vida. É nesta teia que as identidades, individuais e coletivas, se formam e afirmam; é nas relações: "com os seus" e "com os outros" que "o mesmo" e "o outro" se constituem e se definem. A identidade, quando compreendida neste processo de (inter)relações é dinâmica e socialmente constituída, como diria Barth (1998), nas fronteiras étnicas e culturais.

Nessa direção Marín (2003) compreende a cultura como um processo, portanto, algo dinâmico que vem ocorrendo interruptamente em todos os contextos humanos, um processo de formação, transmissão e modos de expressão de símbolos, códigos, modos, valores, que reforçam o valor e o sentimento de identidade, assim como manifesta suas influências, mutações, negociações que ocorrem no contato com a diversidade.

As culturas e identidades, segundo Grando (2009) são:

Como franjas de uma cortina que se tocam quando balançadas pelo vento, cada cultura mantém-se presa a sua parte - seu grupo - ao mesmo tempo em que é tocada pelo contato com o outro grupo étnico. Como franjas que, ao 
sabor do vento se aproximam, se distanciam, se entrelaçam, as culturas, dependendo do contexto histórico, interpenetram-se, entrelaçam-se, aproximando-se ou distanciando-se. Cada cultura expressa um conjunto de escolhas pelas quais se diferencia e que são aperfeiçoadas permanentemente, utilizando no tempo e no espaço, na ordenação da Terra e do cosmo, seu lugar nesse universo distinto e significativo, em que pensam as relações interétnicas e interculturais estabelecidas e os seus contextos históricos específicos (GRANDO, 2009, p. 21-22).

Assim como a alteridade é uma lógica de pensamento e ação, o etnocentrismo é o seu correlato oposto. Podemos entender o etnocentrismo como a análise e consideração da cultura de outros povos/grupos a partir dos aspectos e valores culturais do nosso próprio sistema simbólico, ou como na analogia de Laraia (1999), trata-se de ver a cultura do outro pelas lentes de nossa própria cultura, uma vez que [...] o homem vê o mundo através de sua cultura tem como consequência a propensão em considerar o seu modo de vida como o mais correto e o mais natural", produzindo nas relações interétnicas o que o autor denomina de "etnocentrismo" que se torna responsável [...] pela ocorrência de numerosos conflitos sociais (LARAIA, 1999 p. 75).

Outra consequência do etnocentrismo é o preconceito, entendido por Rezende (2004, p. 17) como a: [...] atitude negativa que tem a intenção de criar um ambiente de desigualdade, que não considera a diferença entre pessoas ou grupos e que põe o outro em situação de desigualdade.

Cardoso de Oliveira (1976, p.5-6) postula que: [...] uma identidade que surge por oposição, não se afirma isoladamente. No caso da identidade étnica, ela se afirma negando a outra identidade, 'etnocentricamente' por ela visualizada; o etnocentrismo (como sistema de representações) seria a comprovação empírica da identidade étnica em seu estado mais primitivo, pois por meio dos nossos valores nós não só julgamos os valores dos outros como também julgamos os outros.

Para Geertz (2001) o problema do etnocentrismo é que nos impede de descobrir em que tipo de ângulo no situamos no mundo, isto é, dificulta a compreensão de nós mesmos, do que representamos e onde estamos no mundo. Segundo ele nossas crenças e valores são apropriados por nós, justamente porque nos é ensinado a partir do contexto que vivemos e, ao considerá-las superiores, desenvolvemos o etnocentrismo.

Revista Interinstitucional Artes de Educar. Rio de Janeiro, V. 4 N. 3 - pag 623-654 (out/2018 - jan/ 2019) 


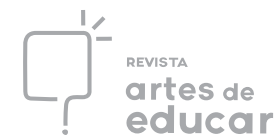

Matos (2008), por outra via, considera a alteridade o reconhecimento lógico do "outro" enquanto outro, ou seja, necessariamente reconhecendo as diferenças históricas e culturais que marcam e diferenciam o "eu/mesmo" do "outro", o que é a única via possível de se estabelecer relações cujo fundamento é o respeito e a paz. Relações estas que passam a se dar não no "meu mundo", mas no "nosso mundo", compartilhado e entendido em suas particularidades e diferenças, ora partilhadas ora distanciadas num mesmo sistema social.

Nessa dinâmica da identidade, Barth (1998) traz a compreensão das fronteiras étnicas, que apesar de não serem fixas, são criadas por partes dos grupos étnicos a partir dos sinais "diacríticos" que demonstram que eles são diferentes em certo sentido, e que concomitantemente, partilham do mesmo sistema social. Cada grupo social/étnico entra em relação com o outro a partir da sua cultura, do seu sistema de símbolos e significados e, a partir deles, articula suas estratégias de relação/resistência/adaptação em que essas mesmas diferenças são constantemente reinterpretadas e reformuladas no contexto da própria cultura (GRANDO, 2004).

Até os estudos de Barth (1998) a teoria antropológica sobre etnicidade assumia que cada grupo se desenvolveria em um relativo isolamento, o que esvaziava de conteúdo e importância as relações que ocorrem nos contatos, nas fronteiras; posteriormente, a análise sobre grupos étnicos rompe com a suposta neutralidade e ingenuidade dos estudos de até então que consideravam ser possível categorizá-los por meio de um conjunto de traços culturais que distinguissem um grupo de outro, dado que coloca no centro da questão justamente as relações com o outro, relações essas que se dão nas fronteiras. Vale lembrar que as fronteiras a que se refere Barth (1998) não são fronteiras/barreiras físicas, as fronteiras dos grupos étnicos são muito mais sociais do que físicas, mas podem ter sim um correlato físico, como o meio urbano ou as escolas.

No mesmo sentido Berger e Luckman (1995) consideram a identidade como um fenômeno social, portanto, dinâmico, um aspecto do indivíduo ou do grupo que é atribuído, sustentado e transformado socialmente. Com estas novas concepções de grupo étnico, o conteúdo cultural não é mais central, preexistente ou superior ao indivíduo, a noção de cultura muda e com ela a conceituação de identidade étnica, que passa a ser ao mesmo tempo inclusão e exclusão: ela identifica o grupo ao mesmo tempo que o diferencia dos demais, 


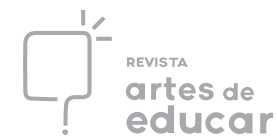

criando a fronteira entre o "nós/o mesmo" e "eles/o outro", no contato contínuo com um sistema social mais abrangente e também dinâmico.

Nesta nova lógica, Barth (1976) propõe que a identidade deixe de ser considerada como algo "natural" para ser analisada como um valor resultante de um processo de relação entre os grupos, as características que devem ser tomadas em conta são aquelas definidas como significativas pelo próprio grupo que ao interagir com demais populações, determina suas fronteiras. Assim, não é a diferença cultural que está no cerne da origem da etnicidade, mas sim a comunicação cultural que permite estabelecer fronteiras entre os grupos, por meio de símbolos que podem ser compreendidos pelos grupos (POUTGNAT; SEYFERTH, 1998 apud OLIVEIRA, 2010, p.18, grifo nosso).

Brandão (1986) lembra que as identidades étnicas não são coisas dadas, mas: [...] são construções, são realizações coletivas motivadas, impostas por alguma ou algumas razões externas ou internas ao grupo, mas sempre e inequivocamente realizadas como um trabalho simbólico dele, em sua cultura e com a sua cultura (1986, p. 110).

Sendo a identidade étnica marcada nas e pelas relações contrastivas, o processo identitário é aberto às manipulações pelos grupos em contrastes, sejam étnicos ou nacionais (CARDOSO DE OLIVEIRA, 2000); a análise das relações que acontecem nas fronteiras e o reconhecimento de que os grupos se constituem e (re)afirmam nas relações com o outro se tornou patente e inadiável dadas próprias permanências culturais em meio aos Estados Nações e à globalização (BARTH, 1998).

Agier (2001) lembra que a identidade coletiva consiste no fato de ser o "outro" de alguém, para Barth (1998) a identidade, em especial a identidade étnica, se afirma pela contraposição ao outro, ela é relacional e se define em relação a um "outro" diferente de "nós". Roberto Cardoso de Oliveira (2000) considera que a etnicidade se refere a relações entre grupos no interior de sociedades envolventes, dominantes, culturalmente hegemônicas, ou seja, em meio a Estados Nações o termo etnicidade poderia também ser aplicado a modalidades de interação bem menos complexas, como uma maneira de interação entre grupos culturais que atuam em contextos sociais comuns.

É necessário considerarmos que as relações nas fronteiras são relações de poder, ou como diria Bourdieu (1989) é um campo de luta identitária, chamando a atenção sobre como o poder de alguns grupos sociais influência nesta construção; com o reconhecimento das

Revista Interinstitucional Artes de Educar. Rio de Janeiro, V. 4 N. 3 - pag 623-654 (out/2018 - jan/ 2019) "Educação Intercultural: aprender com os povos originários do Sul a decolonizar a educação" DOI:10.12957/riae.2018.38702 
relações de poder que existem nas fronteiras, há o reconhecimento do desequilíbrio de poder na e para definição das identidades.

Segundo Cardoso de Oliveira (1978) o contato entre grupos étnicos diferentes, mas necessariamente vinculados entre si são descritos por meio da friç̧ão, visto que nestes encontros as contradições se manifestam em tensões (contradições latentes) e conflitos (contradições manifestas), lembrando que se trata de relações dinâmicas e contextualizadas em um todo social, por exemplo, uma sociedade.

A análise da interdependência proveniente do contato interétnico - lembrando que o termo interdependência não pretende eliminar a desigualdade de poder existente nesta relação, mas sim entender as relações existentes entre atores sociais, e das fontes e canais institucionais de conflito envolvidos nesta situação - em que não há neutralidade e sim uma força maior por parte de um grupo do que de outro, também pode respaldar-se no conceito de situação histórica, de Oliveira Filho (1998):

[...] capacidade que assume temporariamente uma agência de contato de produzir, através da imposição de interesses, valores e padrões organizativos, um certo esquema de distribuição de poder e autoridade entre os diferentes atores sociais aí existentes, baseado em um conjunto de interdependências e no estabelecimento de determinados canais de resolução de conflito (OLIVEIRA FILHO, 1998, p.59).

Cardoso de Oliveira (1996) contribuiu nesta discussão ao propor o conceito de fricção interétnica, que procura compreender a estrutura e a dinâmica das relações entre grupos étnicos distintos inseridos em um uma relação de sujeição e dominação em meio a um sistema social, concebido como uma "totalidade sincrética", em que mesmo com interesses opostos os estes grupos são interdependentes:

[...] Note-se bem que não se trata de relações entre entidades contrárias, simplesmente diferentes ou exóticas, umas em relação a outras; mas contraditórias, isto é, que a existência de uma tende a negar a da outra. E não foi por outra razão que nos valemos do termo fricção interétnica para enfatizar a característica básica da situação de contato (CARDOSO DE OLIVEIRA, 1996, p.46). 
Assim quando pensamos no intenso movimento migratório de indígenas para cidade, somos levados a perceber e conceber a cidade, o espaço urbano, como uma fronteira, em que grupos se encontram, se relacionam e, por isso mesmo, manifestam e (re)afirmam suas identidades; identidades e perspectivas que, segundo Luciano (2006), variam entre indígenas urbanos e aldeados, sem com isso significar uma exclusão.

Os índios aldeados vivem dos recursos oferecidos pela natureza, enquanto os índios que moram em centros urbanos vivem geralmente de prestações de serviços e como mão-de-obra do mercado de trabalho. Disso resulta que a perspectiva dos índios aldeados estará mais focada para a valorização dos seus conhecimentos tradicionais de produção, consumo e distribuição de bens, enquanto os índios de centros urbanos estarão propensos a apostar na qualificação profissional e na capacidade de inserção no mercado local e global. $O$ fato demonstra, por exemplo, a necessidade de se pensarem projetos de escolas e de formação diferenciada para as duas realidades indígenas distintas (LUCIANO, 2006, p. 24).

O êxodo para os centros urbanos é realidade em várias regiões do país, praticado por grupos familiares indígenas esse movimento migratório revela uma profunda dinamicidade entre a aldeia e a cidade. A migração não ocorre apenas em direção às cidades, há o retorno também aos territórios tradicionais; sendo que as perspectivas distintas entre índios urbanos e aldeados não pode justificar o estabelecimento de fronteiras rígidas entre duas realidades. Segundo esse autor isto significaria uma outra forma de exclusão e de discriminação, porque ambas as perspectivas são parte de uma mesma referência sociocultural e étnica (LUCIANO, 2006, p. 24).

Indígenas nas cidades brasileiras é uma realidade, seja em grandes centros urbanos ou cidades do interior. Segundo análise de Azevedo (2011) com relação à presença indígena nos municípios brasileiros:

[...] dos 5.565 municípios, 1.085 não têm nenhuma população autodeclarada indígena, 4.382 têm menos do que $10 \%$ de sua população declarada indígena e 12 municípios possuem mais de $50 \%$ da população contabilizada como indígena, sendo eles majoritariamente da região norte e nordeste. São 86 os municípios com 10 a $50 \%$ da população indígena. Como a proporção varia muito de acordo com o tamanho dos municípios e a população indígena no Brasil [... é] de pequeno porte (se compararmos, por exemplo, com o 
tamanho de outros povos indígenas da América Latina), a presença indígena em municípios brasileiros é bastante expressiva. (AZEVEDO, 2011, s/n).

Neste contexto, é comum ouvir que a migração destes indígenas para o espaço citadino resulta na desconfiguração de sua cultura e incorporação dos costumes dos não índios, levando a extinção de sua cultura tradicional/indígena. Nunes (2010) compreende que neste imaginário predomina:

[...] uma associação entre índios e floresta/natureza, por um lado, e nãoíndios e cidade/civilização , por outro. Num tal contexto, a passagem (lógica) dos indígenas ao ambiente urbano tende a ser pensado como um processo de "desagregação cultural", aculturação, tornar-se igual a outro e, em consequência, perder-se de seu próprio ser (NUNES, 2010, p. 11).

Esta perspectiva surge do pensamento evolucionista que considera os Povos Indígenas como culturas em estágios inferiores, cujo único fim seria a integração e assimilação à cultura global (LUCIANO, 2006). Entretanto, o que se percebe é a autoafirmação de indígena no contexto citadino, no qual se entende a migração para a cidade como uma oportunidade de luta por reconhecimento, por estudo, por direitos e pela cidadania.

Para Pacheco de Oliveira (2012) é preciso que esse deslocamento geográfico do meio rural para as áreas urbanas seja inserido num processo maior e de longa duração de incorporação dos indígenas em múltiplos nichos da sociedade brasileira, seja no campo [...] seja nas cidades, independente do porte das cidades ou distância de seus territórios. (2012, p.1079).

Roberto Cardoso de Oliveira (1978) nos traz a inserção do indígena no espaço urbano como uma possibilidade de continuar indígena, à despeito do território. Para Nunes (2010) o atual cenário dos Povos Indígenas, qual seja de presença, utilização e apropriação das cidades, traz muitos e novos desafios à etnologia indígena, mas ao contrário do pessimismo de Malinowski os povos nativos não estão desaparecendo diante de nossos olhos (2010, p.10).

A despeito da presença indígena nas cidades se manifestar há muitos anos, apenas muito recentemente parece ter se tornado legítima e de acordo com levantamento realizado por Nunes (2010), primeiro houve o pioneiro trabalho de Cardoso de Oliveira, (1978) com os Terenas, e nos anos 1980 como quatro dissertações de mestrado por ele orientadas 


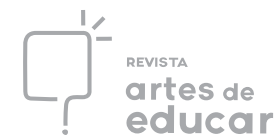

(ROMANO, 1982; LAZARIN 1981; FÍGOLI 1982; PENTEADO, 1980) a respeito dessa questão; em seguida, somente a partir de 2000 esta temática volta a aparecer em alguns trabalhos antropológicos.

Segundo o levantamento bibliográfico realizado por Oliveira (2013) a partir de 2000 as pesquisas voltadas à questão do contato interétnico buscam romper com o discurso de dominação e sujeição das populações indígenas e compreender que o espaço urbano passa a ser reinterpretado pelo indígena de acordo com sua lógica e cosmologia, constituindo-se esse espaço como mais uma fronteira interétnica.

Para Luciano (2008) a presença indígena na cidade não é um fenômeno recente:

[...] nova é a visibilidade que essa população está ganhando. Até então eram populações invisíveis e totalmente excluídas e negadas do campo dos direitos indígenas, de modo que sofriam dupla discriminação: de serem parte dos segmentos empobrecidos das periferias das cidades e excluídos dos direitos indígenas oferecidos aos índios de aldeias (2008 apud SANTOS, 2014, p.56).

Nunes (2010) também nos traz a perspectiva da cidade como ambiente, ou seja, espaço físico e lócus de um modo de existência específico; assim há um duplo processo (como mencionado desde Roberto Cardoso de Oliveira) de presença da cidade na aldeia (pela incorporação de bens de consumo e costumes e valores urbanos) e de persistência da aldeia na cidade (pela manutenção dos valores e relações de parentesco tradicionais); e como mais um espaço ocupado e utilizado pelos grupos indígenas e, portanto, ocupado e utilizado em sua lógica:

Pois tomando cerveja de mandioca ou cerveja industrializada, comendo frango ou caititu, pintando o corpo ou usando "roupas de branco", estamos falando de populações cuja forma de pensar é muito distinta da nossa; e não poderíamos supor que os índios passassem a pensar com o nosso próprio esquema cognitivo-categorial apenas por que se apropriam de nossas coisas. Não poderíamos, igualmente, supor que a busca ativa por incorporação de capacidades de seres outros, através da experimentação de seus pontos de vista, por exemplo, só fosse operativa para outros grupos indígenas ou certos animais. Nós, não índios, também somos Outros dos índios. E se assim o é, por qual motivo suporíamos, a priori, que isso se daria de outra forma quando os índios estão nas cidades? (NUNES, 2010, p.12) 
Voltando a Oliveira (2013) e seu levantamento bibliográfico, os estudos dos contatos interétnicos trazem novas abordagens ao trabalho iniciado por Cardoso de Oliveira:

[...] buscando compreender o contato interétnico além de relações de dominação e sujeição dos índios por parte da sociedade envolvente (MELO, 2009). Logo, a perspectiva dualista entre cidade e aldeia é alterada e esses dois mundos não se opõem mais e sim estão em contínua interação. Ademais, como pontuou Barth (1988, p. 188), as (...) as diferenças culturais podem permanecer apesar do contato interétnico e da interdependência dos grupos (OLIVEIRA, 2013, s/n).

A diversidade cultural e histórica dos Povos indígenas do Brasil é enorme, como é enorme a diversidade com que se manifesta a presença indígena na cidade, demonstrando que não há uma situação de urbanidade, mas várias e que cada caso, cada especificidade implica num modo de se relacionar com ela; Assim, ao pensar um caso de inserção indígena na cidade - e isso deve ser feito empiricamente -, há de se levar em conta sua sócio-cosmologia, e dentro desta "estrutura" geral, sua noção específica de territorialidade (NUNES, 2010, p.19).

Bartolomé (2006) considera que a migração e a etnogênese são partes constitutivas do processo histórico das sociedades nativas; segundo ele este conceito se deu com vistas ao: [...] processo histórico de configuração de coletividade étnica como resultado das migrações, invasões, conquistas, fissões e fusões (2006, p.39).

Luciano (2006) considera o processo de etnogênese num contexto de reetinização, ou seja, de emergências e reinvenções das etnias:

[...] povos indígenas que antes, por pressões políticas, econômicas e religiosas ou por terem sido despojados de suas terras e estigmatizados em função dos seus costumes tradicionais, foram forçados a esconder e a negar suas identidades tribais como estratégia de sobrevivência - assim amenizando as agruras do preconceito e da discriminação - estão reassumindo e recriando as suas tradições indígenas (2006, p. 28).

Um fenômeno em que, diante de determinadas circunstâncias históricas, um povo étnico, que havia deixado de assumir sua identidade étnica por razões também históricas, consegue reassumi-la e reafirmá-la, recuperando aspectos relevantes de sua cultura tradicional (2006, p. 39). 
Para concluir, Mubarac Sobrinho $(2010,2014)$ ao abordar a questão dos índios urbanos no Brasil indica de algum modo uma concepção mais elástica dos movimentos migratórios e dos processos de urbanização em que está envolvida parte significativa destes povos.

Segundo levantamento realizado por Santos (2014) inúmeros são os fatores que levam os indígenas, individualmente ou em núcleos familiares, a migrarem para cidade; entre eles a autora destaca: a contínua e progressiva perda de territórios tradicionais, conflitos internos às aldeias e busca de serviços básicos, como a educação escolar/universitária e o atendimento de saúde. Há ainda o surgimento de cidades no interior de aldeias e inúmeros casos encontrados pela autora que demonstram um fluxo constante entre a aldeia e a cidade.

Tanto os indígenas que vivem no contexto urbano como aqueles que vivem em territórios tradicionais, estão em constante fluxo entre a Terra Indígena e a cidade. Estabelecendo as fronteiras étnicas mais visíveis, marcada pelo entrecruzamento de etnias, estabelecendo fronteiras dinâmicas por meio de enfrentamentos e das interações no cotidiano (SANTOS, 2014, p. 62).

Porém, os elementos básicos que determinam os deslocamentos de populações indígenas para a cidade devem ser procurados e identificados nos contextos próprios de contato e relação com a sociedade envolvente (TEIXEIRA et al, 2009). Silva (2006) ao questionar e refletir sobre as condições históricas e as atuais necessidades das populações indígenas em contextos urbanos, afirma que:

As políticas públicas que são voltadas para as populações indígenas sempre estiveram pautadas pela perspectiva "integracionista" e tutelar, que visa conduzir, dentro de parâmetros "evolutivos", as sociedades e culturas indígenas para a condição de "civilizados", desfigurados sob a ideologia de uma "comunhão nacional" homogênea (SILVA, 2006, p.34).

O que nos leva novamente à Luciano (2008 apud SANTOS, 2014) que ressalta:

Com o processo de democratização do país os processos de reafirmação étnica e identitária vieram à tona e junto às políticas de ações afirmativas, essas populações começaram a ganhar espaços de visibilidade e o movimento indígena e as políticas públicas foram pressionadas a olhar para eles também como sujeitos de direitos específicos, o que é absolutamente legítimo (2008 apud SANTOS, 2014, p. 56). 
As referências às populações indígenas urbanas costumam se relacionar, conforme Souza (2009), ao processo de democratização do país, à reafirmação da identidade étnica (no contexto da legislação internacional, nacional e no contexto das próprias relações sociais) e à consolidação do movimento indígena, aspectos evocados por lideranças e estudantes indígenas que lutam pela transformação de diretos em políticas públicas que alcancem igualmente os Povos Indígenas quer sejam urbanos ou aldeados.

Para Luciano (2006) a realidade atual demanda: [...] estender e consolidar políticas adequadas [...] que não podem ser iguais àquelas voltadas para as aldeias e as terras indígenas, uma vez que as demandas e perspectivas são diferentes em muitos aspectos. (2006, p. 4).

O movimento migratório de indígenas em direção ao meio urbano, estabelecendo moradia fixa ou não, revela entre outros fatores o desejo de reunir informações sobre esse "outro" (não indígena); com isso, a cidade torna-se também um espaço didático, um espaço privilegiado de aprendizagem. Nos últimos anos no Brasil o protagonismo do movimento indígena e o: [...] viés político e urbano dessa mediação vêm revelando que os estudantes indigenas e seus familiares de algum modo promovem uma reorganização no modo como pensam a identidade e a participação na vida e na tradição do seu povo. (SOUZA, 2009, p. 7).

No campo da educação escolar, a tendência, hoje, volta-se às famílias indígenas que ampliaram a procura pela escola urbana, quer pela necessidade de continuar o processo de escolarização iniciado nas aldeias, quer por acreditarem que as escolas da cidade lhes oferecem mais recursos, oportunidades e saberes (SANTOS, 2014). Neste sentido podemos dizer que os avanços legais na formação de uma educação escolar indígena diferenciada e bilíngue vêm tendo um bom desenvolvimento, inclusive com ampla participação dos próprios Povos Indígenas; infelizmente não podemos dizer o mesmo quando se trata de políticas de acesso, permanência e qualidade da educação indígena no espaço urbano. 


\section{Formação continuada e suas consequências}

No intuito de compreender como a escola e seus professores engendram a formação continuada e trazem novos conhecimentos e práticas para o cotidiano da escola fizemos a analisado do Projeto Sala de Educador (PSE), dos anos de 2011 a 2015. O Projeto Sala de Educador faz parte da política pública do Estado de Mato Grosso de formação continuada em serviço para os profissionais da educação. A carga horária de trabalho do professor segundo as determinações da Lei de Diretrizes e Bases da Educação Básica (LDB, 1996), deve contemplar o período de aula e atendimento e preparo das atividades, neste último incluído o tempo para a formação continuada.

Segundo Luckesi (2004) o papel da didática se destina a atingir um fim: a formação do educador. Sua concepção de educador traz algumas consequências, tais como: a ação pedagógica se mostra ideologicamente marcada, explicitando as opções teóricas do educador e consequentemente todas as outras opções dessas decorrentes, além de incorrer numa ação comprometida ideológica e efetivamente não burocrática, dada sua construção dialética cotidiana.

Pimenta (1997), respaldada por outros teóricos como Comu e Verginoux e Houssaye, quer deixar claro que a especificidade da formação pedagógica é refletir, não só sobre o que se vai fazer, nem sobre o que se deve fazer, mas sobre o que se faz, ou seja, que o limite do pensar didático não é a ação educativa, mas o refletir sobre a ação, que [...] os saberes pedagógicos só se constituem a partir da prática, que os confronta e reelabora (PIMENTA, p.50, 1997). As novas tendências sobre a formação de professores valorizam o professor reflexivo, aquele que constantemente se forma pelo confronto de seus saberes iniciais com suas experiências práticas e sua reflexão sobre essas experiências, formando seus saberes como praticum; dai a importância de tempos e espaços como o da formação continuada em serviço.

Com base na análise do Projeto Sala de Educador (PSE) de 2011, grupos de estudos são organizados para discussão de temas relevantes ao cotidiano da escola, segundo sua própria comunidade e diagnósticos prévios. Assim, em 2011 os participantes foram divididos segundo a modalidade de ensino (Ensino Médio Integrado ao Profissionalizante - EMIEP - e Semestralidade e EMIEP e Ciclo), entretanto as temáticas trabalhadas foram as mesmas. 
Houve a apresentação de um cronograma com as informações detalhadas dos encontros (data, temática, mediador, referência, carga horária). Foram abordadas aproximadamente 11 temáticas, que envolveram temas como as orientações curriculares, especialmente para o EMIEP, a integração curricular, a formação de professores, a avaliação e o perfil de escola que o país contemporaneamente demanda. A carga horária de cada temática variou de 3 a 15 horas. Apesar da indicação dos mediadores de cada tema, é consenso entre os professores e gestores que apenas o coordenador responsável por cada grupo mediou os estudos de cada temática, sendo que a mediação por professores participantes do Projeto só começou de fato em 2014.

Em 2012 o projeto também apresentou cronograma detalhado e foram elencados cerca de nove temas, que envolveram a interdicisplinaridade, a avaliação, as dificuldades de aprendizagem, com enfoque na dislexia, a diversidade cultural e a biblioteca escolar, com carga horária variando de 4 horas a 12 horas. Com relação aos mediadores, estes foram apenas a coordenadora do grupo e a bibliotecária. A temática sobre diversidades teve a carga horária de 12 horas, ou seja, três encontros, sendo que em um deles houve a participação de formadores do Centro de Formação de Professores (CEFAPRO), auxiliando no desenvolvimento do estudo.

Em 2013 o cronograma apresentou a mesma estrutura; as temáticas desenvolvidas foram reduzidas para seis, com carga horária de estudo variando de 12 a 16 horas. Os temas abordados continuaram a focar o EMIEP, a avaliação e as dificuldades de aprendizagem (agora a questão do TDAH), foram incluídas as temáticas sobre a CONAE e as competências e habilidades para o ensino médio. Como mediadores foram elencados quatro professores, entretanto novamente apenas a coordenadora do grupo mediou os estudos e atividades.

Em 2014 apenas cinco temáticas foram desenvolvidas, com carga horária variando de 12 a 20 horas. As temáticas seguiram a tendência do ano anterior - EMIEP e integração curricular, competências e habilidades para o ensino médio, a avaliação e a inclusão (Inclusão: metodologias de como trabalhar o processo de ensino aprendizagem com o aluno incluso). Neste foram elencados de 2 a 3 professores como mediadores de cada temática e estes realmente desenvolveram sua função como mediador; à coordenadora do grupo coube auxiliá-los na organização das atividades e no levantamento bibliográfico. 
O PSE 2015 disponibilizado pela coordenação escolar não apresentava o cronograma de atividades nem a distribuição das temáticas, mediadores e carga horária, apresentava somente as temáticas a serem desenvolvidas nos momentos de estudo. Assim temos elencadas as temáticas que demonstram continuidade com as levantadas nos anos anteriores: inclusão (libras), competências e habilidades para o Ensino Médio, avaliação e integração curricular por meio de trabalhos inter/transdisciplinares.

Do ponto de vista da análise documental, notamos que nos Projetos Políticos Pedagógicos analisados (dos anos de 2011, 2013 e 2015) há reconhecimento da presença indígena na escola; há o entendimento que uma educação que respeita e valoriza os direitos humanos deve reconhecer todas as diversidades e diferenças presentes na escola, sendo esta a diferença - um princípio educativo. Por outra via, no entanto, o campo da ação, do destinamentos dos recursos financeiros, das reformas, dos esforços formativos e aquisição de materiais ficam voltados à questão da inclusão dos alunos portadores de necessidades especiais.

Esse esforço formativo, voltado à inclusão dos portadores de necessidades especiais também é percebido na formação continuada em serviço, em meio aos Projetos Sala de Educador analisados (de 2011 a 2015) em que a temática da inclusão por meio dos estudos sobre dislexia, TDAH e libras se fazem presentes em todos os anos, somando carga horária de aproximadamente 70 horas e a temática da diversidade, que entre outras diversidades trouxe a questão indígena e especificamente Xavante, foi estudada apenas no ano de 2012, em 12 horas de formação.

Com base em dados levantados nas Atas de Resultados Finais disponibilizadas pela secretaria temos os seguintes quadros:

Tabela 1 - Alunos PNE matriculados por série e situação final

\begin{tabular}{llcccc}
\hline Ano & Turma & Aprovado & Reprovado & Desistente & Total \\
\hline \multirow{2}{*}{2011} & $1^{\circ}$ Ano & 03 & -- & -- & 05 \\
& $2^{\circ}$ Ano & 02 & -- & -- & \\
& & & & -- & \\
\multirow{2}{*}{2012} & $1^{\circ}$ Ano & 03 & -- & -- & 06 \\
& $2^{\circ}$ Ano & 02 & -- & -- & \\
& $3^{\circ}$ Ano & 01 & -- & & \\
\hline
\end{tabular}

Revista Interinstitucional Artes de Educar. Rio de Janeiro, V. 4 N. 3 - pag 623-654 (out/2018 - jan/ 2019) 


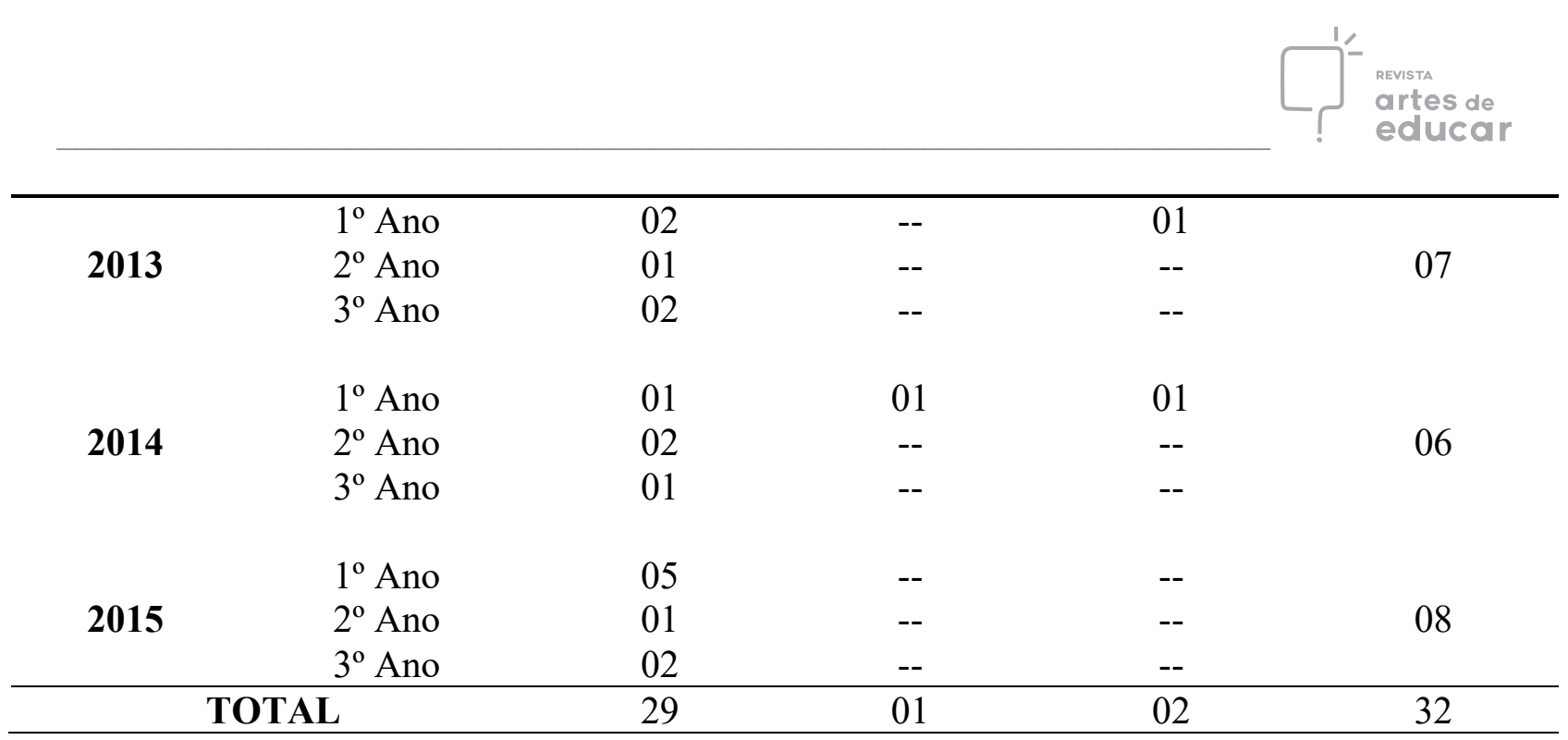

Tabela 2 - Alunos indígenas matriculados por série e situação final

\begin{tabular}{|c|c|c|c|c|c|c|}
\hline Ano & Turma & Aprovado & Reprovado & Transferido & Desistente & Total \\
\hline \multirow{2}{*}{2011} & $1^{\circ}$ Ano & 01 & 01 & -- & - & \multirow{2}{*}{03} \\
\hline & $2^{\circ}$ Ano & -- & -- & 01 & -- & \\
\hline \multirow{3}{*}{2012} & $1^{\mathrm{o}}$ Ano & 06 & 02 & -- & 01 & \multirow{3}{*}{17} \\
\hline & $2^{\circ}$ Ano & 01 & 04 & -- & 01 & \\
\hline & $3^{\circ}$ Ano & -- & -- & 02 & -- & \\
\hline \multirow{2}{*}{2013} & $1^{\circ}$ Ano & -- & 02 & 04 & -- & \multirow{2}{*}{13} \\
\hline & $2^{\circ}$ Ano & 03 & -- & 03 & 01 & \\
\hline \multirow{3}{*}{2014} & $1^{\circ}$ Ano & 04 & 04 & 02 & -- & \multirow{3}{*}{19} \\
\hline & $2^{\circ}$ Ano & -- & 02 & 01 & -- & \\
\hline & $3^{\circ}$ Ano & 01 & 02 & 02 & 01 & \\
\hline \multirow{2}{*}{2015} & $1^{\circ}$ Ano & -- & 03 & -- & 04 & \multirow{2}{*}{14} \\
\hline & $2^{\circ}$ Ano & 01 & 02 & 03 & 01 & \\
\hline \multicolumn{2}{|c|}{ TOTAL } & 17 & 22 & 18 & 09 & 66 \\
\hline
\end{tabular}

Os dados das Atas Finais nos mostraram que entre 2011 e 2015 tivemos 32 matrículas de alunos portadores de necessidades especiais, com um total de 90,62 \% de aprovação; já entre os indígenas foram 66 matrículas, com 25,75\% de aprovação no total. O maior número de aprovações dos alunos indígenas se deu ano de 2012, com 7 (sete) aprovações num total de 17, ou seja, 41,17\%. Não podemos relacionar diretamente os impactos dos estudos sobre o 


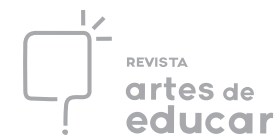

povo Xavante e sua cultura em meio o Projeto Sala de Educador e o índice de aprovação, mas é claro que essa correlação nos salta como possível, ainda mais se considerarmos as porcentagens de aprovação dos outros anos analisados: no ano de 2011 foram 33\%, em 2013 tivemos 23,07\% de aprovação e em 2014 e 2015, 26,31\% e 7,14\% respectivamente.

Esses dados nos revelam um persistente fracasso escolar dos alunos indígenas, assim como o percebido por Mubarac Sobrinho (2010). Segundo este autor a escola deveria representar a possibilidade de aprender a se relacionar com a sociedade envolvente sem perder ou desqualificar sua própria cultura; o que não é verificado nas escolas por ele estudadas em que há a desvalorização da cultura dos povos em questão e a supervalorização da cultura urbana, gerando uma massificação e invisibilidade dos grupos minoritários, como o percebido nestes dados.

\section{Considerações finais}

Sobre a questão das diversidades pudemos notar que a chave analítica e prática da inclusão, quase exclusivamente dos portadores de necessidades especiais, é dominante; assim aspectos considerados inovadores, como a lei 11.645/08 e a educação intercultural são amplamente desconhecidos, ou apenas mencionados. Entendemos que as formações continuadas, em serviço ou não, são de extrema importância para o (re)conhecimento de outras diversidades, como a presença indígena na escola, e para dar subsídios para os professores se sentirem seguros em trazer e abordar este tema em sala de aula.

Entendemos que a escola deveria representar a possibilidade de aprender a se relacionar com a sociedade envolvente sem perder ou desqualificar sua própria cultura; o que, infelizmente, não foi verificado no caso estudado. A diversidade cultural e histórica dos Povos indígenas do Brasil é enorme, como é enorme a diversidade com que se manifesta a presença indígena na cidade, demonstrando que não há uma situação de urbanidade, mas várias e que cada caso, cada especificidade implica num modo de se relacionar com ela. Assim, ao pensar o caso da inserção do Xavante em Nova Xavantina, devemos levar em conta sua sócio-cosmologia, o que também deve ser feito pela escola que recebe esses alunos.

Essa percepção e esse entendimento devem ser feitos com base na interculturalidade, ou seja, numa prática de vida que possibilita a convivência e coexistência entre culturas e

Revista Interinstitucional Artes de Educar. Rio de Janeiro, V. 4 N. 3 - pag 623-654 (out/2018 - jan/ 2019) 
identidades, com base no diálogo entre diferentes, visando à superação da intolerância e da violência entre indivíduos e grupos sociais distintos. Essas novas relações possibilitam o entendimento da escola em sua dimensão sociocultural, como um espaço de fronteira, em que novas e múltiplas identidades entram em contato e estabelecem novos níveis de relação, assim como diferentes estratégias de manutenção e defesa identitária e étnica.

Neste sentido é imprescindível que todos os educadores da rede pública de ensino se apropriem de conhecimentos básicos sobre os povos indígenas do Brasil: quem são, quantos são, como vivem, aspectos próprios de cada cultura, como se organizam, entender a trajetória histórica e cultural dos povos indígenas do Brasil e daqueles que circundam as escolas e cidades, suas estratégias e resistência para manutenção de sua cultura e de seus direitos enquanto povos diferenciados e, ainda assim, pertencentes à sociedade nacional.

\section{REFERÊNCIAS}

AGIER, M. Distúrbios identitários em tempos de globalização. Mana, n.7, 2001, p.7-33.

AZEVEDO, M. M. O Censo 2010 e os Povos Indígenas. Agosto/2011. Disponível em https://pib.socioambiental.org/pt/c/no-brasil-atual/quantos-sao/o-censo-2010-e-os-povosindigenas. Acessado em 25 de julho de 2016.

LUCIANO, G. Dos S. O indio brasileiro: o que você precisa saber sobre os povos indígenas no Brasil de hoje. Brasília: Ministério da Educação, Secretaria de Educação Continuada, Alfabetização e Diversidade - SECAD. LACED, 2006. (Coleção Educação para todos, 12). (Vias dos saberes, n. 1).

BARTH, F. Grupos étnicos e suas fronteiras. In: POUTIGNAT, P; STREIFF-FENART, J. Teorias da etnicidade. São Paulo: UNESP, 1998.p.188-227.

BARTOLOMÉ, A. M. As Etnogêneses: velhos atores e novos papéis no cenário cultural e político. In: Revista Mana, volume 12, Museu Nacional, Rio de Janeiro, 2006.

BERGER, P. e LUCKMAN, Th. 1995 [1968]. La construcción social de la realidad (Amorrortu: BsAs).

BOTH, S. J. Da aldeia a cidade: o cotidiano de estudantes Paresi em escolas urbanas de Tangará da Serra/MT. (Dissertação de Mestrado de Educação). Universidade Federal de Mato Grosso, Cuiabá, 2006.

BOURDIEU, P. A identidade e a representação: elementos para uma reflexão crítica sobre a idéia de região. In: O poder simbólico. Lisboa: Difel, 1989. p. 107-132. 
BRANDÃO, C. R. Identidade e etnia: construção da pessoa e resistência cultural. São Paulo: Brasiliense, 1986.

BRASIL, Lei 11.645/2008. Inclusão no currículo oficial da rede de ensino a obrigatoriedade da temática "História e Cultura Afro-Brasileira e Indígena". Disponível em:

http://www.planalto.gov.br>Acesso 13 Set de 2013.

BRASIL, Lei no 9394/96 - Lei de Diretrizes e Bases da Educação Nacional. Estabelece as diretrizes e bases da educação nacional. Disponível em $<$ www.planalto.gov.br $>$. Acesso em: 25 Jun. 2013.

CARDOSO DE OLIVEIRA, R. Identidade, etnia e estrutura social. São Paulo: Pioneira, 1976.

CARDOSO DE OLIVEIRA, R. Os (des)caminhos da identidade. Revista Brasileira de Ciências Sociais, São Paulo, v. 15, n. 42, p. 7-21, 2000.

CARDOSO DE OLIVEIRA, R. Urbanização e tribalismo: a integração dos índios Terêna numa sociedade de classes. Rio de Janeiro: Zahar, 1978.

EICHHOLZ, G. L. Aprendizagens da Lei 11.645/08 na experiência intercultural dos XII Jogos dos Povos Indígenas em Cuiabá-MT. Dissertação (mestrado) - Universidade Federal de Mato Grosso, Instituto de Educação, Programa de Pós-Graduação em Educação, Cuiabá, 2015. $230 \mathrm{f}$.

FLEURI, R. M. Intercultura e educação. Rev. Bras. Educ., Rio de Janeiro, n. 23, p. 1635, Aug. 2003 . Disponível em $<$ http://www.scielo.br/scielo.php?script=sci _arttext\&pid=S1413-24782003000200003\&lng=en\&nrm=iso $>$. Acessado em 25 de Junho de 2015. http://dx.doi.org/10.1590/S1413-24782003000200003

GEERTZ, C. Os usos da diversidade. In: Nova luz sobre a antropologia. Rio de Janeiro: Jorge Zahar Ed., p. 66-85, 2001.

GRANDO, B. S. Corpo e educação: As relações interculturais nas práticas corporais Bororo em Meruri. Florianópolis: UFSC, 2004 (Tese de Doutorado).

GRANDO, B. S. "O Jogo da educação do corpo e a identidade Bororo em espaços de fronteiras étnicas e culturais". In GRANDO, B.; PASSOS, L. A. (Orgs). Eu e o Outro na escola: contribuições para incluir a historia e a cultura dos povos indígenas na escola. Cuiabá. EdUFMT, 2010.

HALL, S. A identidade cultural na pós-modernidade. São Paulo: DP\&A, 2001.

INSTITUTO SÓCIO AMBIENTAL. (2011). Disponível em: < http://pib.socioambiental.org/pt/c/0/1/2/populacao-indigena-no-brasil $>$. Acessado em $02 \mathrm{de}$ outubro de 2014.

Revista Interinstitucional Artes de Educar. Rio de Janeiro, V. 4 N. 3 - pag 623-654 (out/2018 - jan/ 2019) 
JOHNSON, A. G. Dicionário de sociologia: guia prático da linguagem sociológica. Rio de Janeiro, Ed. Jorge Zahar. 1997.

LARAIA, R. de B. Cultura: um conceito antropológico. Rio de Janeiro: Jorge Zahar editora. 1999

MARÍN, J. A perspectiva intercultural como base para um projeto de educação democrática: povos autóctones e sociedade multicultural na América Latina. Revista: Visão Global, Joaçaba, v. 13, n. 1, p. 13-52, jan./jul. 2010.

Disponível em <http://www. editora.unoesc.edu.br Acessado em 19 de abril de 2016.

MARÍN, J. Dimensão histórica da perspectiva intercultural, educação, estado e sociedade. In: Revista Grifos: Dossiê Educação Intercultural. Telmo Marcon (org.). n. 15, maio 2003. Chapecó, SC : Argos Editora, p. 69-88.

MARTINS, J. de S. Fronteira: a degradação do outro nos confins do humano. São Paulo: Hucitec, 1997.

MUBARAC SOBRINHO, R. S. As Culturas Infantis Indigenas e os Saberes da Escola: Uma Prática Pedagógica Dos (Des)Encontros. Revista Práxis Educacional. Vitória da Conquista v.6, n.8 p.139-156 jan./jun.2010. Disponível em http://periodicos.uesb.br/index.php/praxis/article/viewFile/291/324. Acessado em 04 de outubro de 2014.

MUBARAC SOBRINHO. R. S. Crianças indígenas "urbanas": aproximações a uma historiografia na Amazônia. EcooS- Revista Cientifica, São Paulo, v. 9, n. 2, p. 467- 488. Disponível em: $<$ http://www.redalyc.org/articulo.oa?id=71590211 $>$ acesso em: 09 de outubro de 2014

NEVES, J. G. Cultura escrita em contexto Indígena. Tese (Doutorado em Educação Escolar) - Universidade Estadual Paulista, Faculdade de Ciências e Letras, Campus de Araraquara. Araraquara- SP, 2009.

NUNES, E. S. Aldeias Urbanas ou Cidades Indígenas? Reflexões sobre índios e cidades. Espaço Ameríndio, Porto Alegre, v. 4, n. 1, p. 9-30, jan./jun.2010.

OLIVEIRA FILHO, J. P. de. O nosso governo: os Ticuna e o regime tutelas. São Paulo: Marco Zero, 1998

OLIVEIRA, N. A. de. Os Xavante e a Cidade. In: IV REUNIÃO EQUATORIAL DE ANTROPOLOGIA E XIII REUNIÃO DE ANTROPÓLOGOS DO NORTE E NORDESTE. GT39 - Os indígenas e a cidade: processos identitários, direitos e políticas públicas no contexto urbano. Agosto de 2013, Fortaleza-CE.

RAMOS, A. R. Hierarquia e Simbiose: relações intertribais no Brasil. São Paulo: Hucitec, 1980 . 
REZENDE, G. C. Relação entre Indígenas e não-Indígenas em Escolas Urbanas: um estudo de caso na cidade de Campinápolis - MT. Dissertação de Mestrado em Educação.

Universidade Federal de Mato Grosso, UFMT, Brasil.

2004.

ROSA, L. de M. Encontros e desencontros entre os a'uwêuptabi e os waradzu no espaço urbano de Barra do Garças-MT. 2008. 119f. Dissertação (Mestrado em História) -- Programa de Pós-Graduação em História; Universidade Federal de Goiás, Goiânia, GO, 2008.

RUSSO, K. O povo Xavante e a formação dos "novos guerreiros": o sistema educativo e a educação escolar indígena no Brasil. 2005. 219 f. Dissertação (Mestrado em Ciências Sociais e Educação). Programa de pós-graduação em Ciências Sociais e Educação, Faculdade LatinoAmericana de Ciências Sociais, Argentina, 2005.

SANTOS, V. S. dos. Expressões Identitárias no Espaço Escolar: um estudo com estudantes indígenas de escolas públicas urbanas de Ji-Paraná, Rondônia. Dissertação de Mestrado.

UFMT, Cuiabá - MT. 2014

SEDUC, Projeto Politico Pedagógico da Escola Estadual Juscelino Kubitschek. Assessoria Pedagógica de Nova Xavantina - MT, 2015.

SEDUC, Projeto Sala de Educador da Escola Estadual Juscelino Kubitschek. Assessoria Pedagógica de Nova Xavantina - MT, 2011 a.

SEDUC, Projeto Sala de Educador da Escola Estadual Juscelino Kubitschek. Assessoria Pedagógica de Nova Xavantina - MT, 2012.

SEDUC, Projeto Sala de Educador da Escola Estadual Juscelino Kubitschek. Assessoria Pedagógica de Nova Xavantina - MT, 2013a.

SEDUC, Projeto Sala de Educador da Escola Estadual Juscelino Kubitschek. Assessoria Pedagógica de Nova Xavantina - MT, 2014.

SEDUC, Projeto Sala de Educador da Escola Estadual Juscelino Kubitschek. Assessoria Pedagógica de Nova Xavantina - MT, 2015a.

SILVA, F. A. B.; ARAÚJO, H. E. ; SOUSA, A. L. Diagnóstico da situação das populações indígenas no Brasil. IPEA, 2006. Disponível em: $<$ http://www.scielo.br/>. Acesso em: 15 de março de 2015.

SOUZA, H. C. Entre Aldeia e a cidade, Educação escolar Paresi. (Dissertação Mestrado), Cuiabá: Universidade de Mato Grosso, UFMT, 1997.

TASSINARI, A. M. I. Escola indígena: novos horizontes teóricos, novas fronteiras de educação. In: Lopes da Silva, A.; Ferreira, M. (org.) Antropologia, História e Educação: a questão indígena e a escola. Ed. Global. São Paulo, 2001.

Revista Interinstitucional Artes de Educar. Rio de Janeiro, V. 4 N. 3 - pag 623-654 (out/2018 - jan/ 2019) 
TEIXEIRA. P. et.al. Migração do povo indígena Sateré-Mawé em dois contextos urbanos distintos na Amazônia. Cadernos CRH, Salvador, v. 22, n.57, p.531-546, Set/Dez. 2009.

\footnotetext{
${ }^{i}$ Possui graduação em Licenciatura Plena e bacharelado em Ciências Sociais pela Universidade de São Paulo(2008), mestrado em EDUCAÇÃO pela Universidade Federal de Mato Grosso(2017). Atualmente é professora da Secretaria de Educação do Estado de Mato Grosso, atuando na disciplina de sociologia.

ii Professora da Universidade Federal de Mato Grosso (2011), da Faculdade de Educação Física e do Programa de Pós-Graduação em Educação. Doutora em Educação (2004) e Pós-Doutora em Antropologia Social (2011) pela Universidade Federal de Santa Catarina. Criou o Grupo de Pesquisa COEDUC - Corpo, Educação e Cultura (2004).

${ }_{\text {iii }}$ A Lei 11.645/08 - inclui no currículo oficial da rede de ensino a obrigatoriedade da temática "História e Cultura Afro-Brasileira e Indígena".
} 